\title{
The Alignment of Information Technology and Business Strategy in the Kuwaiti Companies
}

\author{
Bandar Alraggas, Ph.D \\ Business College, Computer and Information \\ System Department, \\ Public Authority of Higher Education, Kuwait
}

\author{
Asaad Alzayed, Ph.D \\ Business College, Computer and Information \\ Systems Department, \\ Public Authority of Applied Education, Kuwait
}

\begin{abstract}
Despite the fact that the business executives remain doubtful about the strategic value of information technology. One of the most critical issues facing organizations in Kuwait today is the alignment of information system strategy with the business goals and objectives. Only $28 \%$ of the surveyed companies in Kuwait claim that their IT objectives aligned to their business strategy which is a very low number. This paper uses a survey to investigate the alignment existence between the business objectives and IT strategy within different companies in different sectors located in Kuwait. The survey questionnaire distributed to IT managers and business executive managers in the selected companies. The suggested survey questionnaires have to do first, with the alignment exist between the IT strategy and the company Business objectives; Secondly, the barriers on strategic alignment arising in those companies.
\end{abstract}

\section{Keywords}

IT/Business alignment, strategic alignment, Alignment barriers, Information Technology

\section{INTRODUCTION}

In the past, when companies start using the IT resources, the development and support units were located within the business departments that they support and mostly, within the financial department in order to control the organizational cost. The reason was primarily that the use of IT was relatively limited and directed toward the specific needs of particular departments. In addition, the need for integrating the technology resources across the organization was limited as well.

As the use of IT resources increased and expanded throughout the business, organizations start modifying their organizational structures and companies started to realize that there was a large duplication of effort across different departments. New technologies, such as client-server, the internet, data warehousing, enterprise resources planning systems (ERP) and cloud computing emphasized the need for centralized information infrastructure in the organization [1].

Nowadays many organizations have created a separate IT department in their organization structure responsible for developing, building and maintaining the new technology as well as supporting information technology resources across the enterprise. This organization structure provided significant benefits to organizations: simplifying the network infrastructure, minimizing maintenance cost, and maximizing IT operational efficiency.

However, [22] argued that this type of organizational structure can lead into coordination difficulties between the IT department and the rest of the organization. These difficulties arise from unclear or unpredictable business missions, objectives and priorities; poor communication; absence of IS management from the business planning process; and unrealistic expectations and lack of sophistication in respect of IT on the part of user managers. Therefore, without a good alignment and coordination between the business strategy, tactical planning of IT and the rest of the organization, a business could have a risk in costly IT failures and a steady decline in competitive ability [3, 21, 23, 29, 43].

The alignment between business and IT strategies again became very important in the early 2000s with the rise of eBusiness [11, 31]. In 2004 US Society of information Management survey, the number one concern for executives was the alignment of business and IT [27].

This research paper will conduct a survey for different kinds of companies in different sectors in the state of Kuwait. The purpose of the survey is to find out whether the IT/Business alignment exist and if it does not exist then what are the barriers and reasons behind it. In addition, the survey should give an indication of managers' attitudes and beliefs about strategic alignment in their organizations.

\section{LITRITURE REVIEW}

The subject of the alignment between business strategy and IT information system strategy has been one of the important topics for the researchers for many years. It is considered as one of the main concerns of the Business managers and one of the key issues in Information system management around the world $[4,16]$. Most of the researchers today emphasize that we should align IT strategy with the company's overall strategy. According to a survey conducted by Computer Science Corp (CSC), the top priority of the IT executive is to align the IT function with their business operation [44].

Many researchers studied the idea of alignment from different perspectives. These studies revealed that there are different types of alignment; Such as strategic alignment, structural alignment, Business alignment, information system alignment, Cross-Dimensional alignment and Alignment mechanism [41]. The majority of research have emphasize that the alignment should be strategic in order to provide highest benefits such as improving competitive advantage and enhancing performance [24, 9].

To support these studies, many researchers have come up with models and planning steps for IT business alignment. For instance, in order to have a full integration between business strategy and IT strategy. [48] suggested a four-stage planning model:

1. Administrative integration- that indicates that there is a little or no effort from the IT to support the business objectives. 
2. Sequential integration- which means that the business plan has one-way relationship when providing general direction for the IT plan.

3. Reciprocal integration- which means that there is a two-way relationship between Business and IT plan.

4. Full integration-. Means that IT and Business plan developed at the same time.

Reich and Benbasat [36] separated two dimensions in the linkage between business and IT planning or strategy:

1. An intellectual dimension, relating to the stability, consistency and validity of IT and business objectives;

2. A social dimension, relating to mutual understanding and commitment between business and IS executives in an organization, with respect to each other's missions, objectives and plans.

Various other researchers have also extended these studies, In order to assess the maturity of Business-IT strategy alignment, professor Luftman has introduced Strategy Alignment Maturity model [26]. This model consists of six alignment maturity criterion along with five levels of maturity. The Six Alignment Maturity Criteria are:

1. Communication maturity: to measure the effectiveness of information exchange between IT and business units in order to determine the understanding of business by IT and vice versa.

2. Competency/Value measurement maturity: to develop business metrics, IT metrics, and metric for assessing both IT and business in order to determine the contribution of the IT organization to business.

3. Governance maturity: to determine who has the right to make a decision and what processes that they will use at different levels to identify the order of importance in procuring the IT resources.

4. Partnership maturity: business's awareness of IT contribution, the relationship between business and IT organization, and the degree of consensus in goal, of mutual trust between them measured in this component.

5. Technology Scope and Architect maturity: the assessment of the abilities of the IT organization in providing the infrastructure, evaluating and managing the newly emerging technologies, and facilitating changes in business process..

6. Skill maturity: Gauge the human-related topics, such as retention, hiring, training, career crossover, etc., along with the organization's readiness against changes, learning, leveraging new ideas.

\subsection{The level of alignment maturity are}

1. Initial or ad-hoc processes: There is no IT-business strategy alignment. The communication is poor. Contribution of one another does not exist. Viewing IT as a cost center and focusing on supporting the back-office only.

2. Committed processes: Improving the Relationship between IT and business. Alignment focuses only on department functions and locations. Viewing the
IT as technical and cost oriented. And there is no link between IT and business objectives.

3. Established, focused processes: At this level, the understanding between IT units and business units is being created. The use of SLA applied throughout the organization. IT becomes valuable to the business. Even though, viewing IT as a cost center, the investment potential is great. Technical and business skills become important to managers.

4. Improved, managed processes: Several processes of strategic alignment have been carried out. The gap between understanding of IT units and business units has been closer than before. IT can take part in decision support and appear as value asset. IT has been viewed as "value service provider and as an enabler of changes" [26]. Organization leverages its IT infrastructure to achieve a competitive advantage.

5. Optimized processes: Applying IT-business strategy alignment across the organization. IT leverages the organization's partners and customers. Organization shares the knowledge, metrics to external entities such as partners, customers, suppliers, etc. IT extended its "reach to encompass the value chains external customers and suppliers" (Luftman, J. 2000). The relationship between IT and business tends to be informal and effective. "The integration of Strategic business and IT planning are across and outside the organization" [26].

Researchers and practitioners have also recognized the benefits of aligning business strategy with IT strategies. Some of these benefits includes (1) increasing organizations return on IT investment; (2) improving companies' competitiveness; (3) enhancing flexibility [2]; and (4) Profitability of organizations [14, 34]. With the alignment, organizations can have the traditional benefits of IT/IS in terms of having an organization's operations accepted by executives [18] as well as obtaining top management support [22]. Byrd and Turner [7] stated that in order for IT to provide competitive advantage, it must be strategic, and have an impact on the "goals, operations, products, or environmental relationships of the organization." Other researchers have suggested that increasing business ownership and accountability for return on IT investment was an effective way to ensure alignment of business strategy and IT strategy [15].

The present paper is to investigate how alignment is sought and achieved in participated companies, and what its implications are for the performance in those companies. We have commenced the research by distributing a questionnaire to different types of organization in the Kuwaiti market, to discover attitudes towards alignment from both IT and Business executives.

\section{DEFINING STRATEGIC ALIGNMENT}

Many researchers and practitioners have defined the strategic alignment between IT strategy and business strategy and in this section we will mention a few. Avison et al. [2] stated that Alignment is the degree to which the IT mission, objective and plans support and are supported by the business mission, objectives and plans. Broadbent and Weill [5] define strategic alignment as the extent to which business strategies are enabled, supported, and stimulated by information strategies. Henderson and Venkatraman [17] refer to strategic alignment 
as selecting appropriate alignment perspectives for achieving business objectives. Whereas strategy in its broadest sense is all about alignment or matching organizational resources with the environmental threats and opportunities [32, 42]. The strategic alignment perspective suggests that the effect of IT on performance depends on the fit and harmony between IT Strategy and corporate strategy $[30,12]$. Therefore, Strategic alignment is a process of creating a harmony between IT and Business strategies and leveraging IT functionalities to create and support new and existing business strategies.

Strategic alignment can also improve business performance [40], maximize the return on IT investment, achieve a competitive advantage, and provide direction and flexibility to react to new opportunities [2]. However, it is important to note the usage and leverage of IT to serve the firm's focus. Tallon et al. [46] identify four types of firms; Unfocussed, operation focused, market focused and dual focused. In unfocused firms, IT had no clear goals and perceived as expense and business necessity, so management undervalues IT potential and delays IT purchases, trying to minimize IT expenses instead of increasing IT investment. While, operation focused firm is concentrating on the operational effectiveness, so it uses IT to reduce the production cost and increase efficiency and productivity by focusing on the quality, speed, flexibility, and time to market [2].

On the other hand, market focused firm concentrates on its strategic position and the value proposition, so it uses IT to enhance its market position by improving the value propositions for customers. Finally, dual focused firm extend its use of IT beyond operational effectiveness to include market research and new market research to achieve strategic positioning and operational effectiveness simultaneously [46].

\section{IMPORTANCE OF INFORMATION TECHNOLOGY TO BUSINESS}

Nowadays, being competitive depends on the effective use of IT to manage the information resources. Many researchers and practitioners have emphasized this concept, for example, Smaczny [45] stated that the high dependency on IT has increased to a level where an IT responsiveness can create a competitive disadvantage. Failure to leverage IT may seriously decrease a firm performance and viability [2]. Bruce [6] warns that the failure to align IT with Business will decrease the IT creditability and reduce the strategic IT investment by providing proactive systems instead of reactive ones. Willcocks [49] identified the value and the impact of IT on the firm's profitability and efficiency and marked four domains that can be affected by the leverage of IT; competitive advantages, cost base efficiency, product delivery, operational feasibility, and capacity to manage [49].

Therefore, it can be seen that IT has moved from simply supporting operational functions as in the old days to being a critical strategic organizational resource which should be shaped to deliver business needs $[17,38,8]$. Broadbent \& Weill [5] stated "Business are highly dependent on IT. " Therefore aligning IT objectives to the business strategy has become very important in order for the company to stay in business and become competitive in the market [10,28].

The IT literature has also noticed the influence of IT on business strategies. Rockart [38] stated that IT could have a strong effect on business strategy. Keen [19] also claimed "IT has become an important aspect of everyday business. It is potentially a key element in competitive positioning." Overall,
IT has become a major organizational resource for executing business strategy $[39,13,35]$.

Given the importance of IT resources to the business operation and the need for the alignment between business and IT strategies. In addition, the lack of similar studies in the Kuwaiti market, we undertook a survey that explore and investigate such alignment in the Kuwaiti organizations and this paper outline the outcomes.

\section{THE SURVEY}

The survey consists of five sections together with a covering letter that explained the purpose of the research study and offered a copy of the result and their interpretation to those who responded.

The survey questionnaires are developed to investigate the existence of the IT/Business alignment and the attitudes of the business executive managers and IT managers towards alignment. It contains five sections each one contains at most six questions. When designing the set of questions, we were guided by similar studies in the literature [25, 36, 37, 4, 33], as well as by a desire to keep the questionnaire to be as simple as possible.

We have sent the questionnaires to a selection of private sector, government sector, financial and retail companies in Kuwait.

The first section of the survey asked for background information including job title and industry sector. The second section concerned about aspect of the existence of alignment between business and IT strategy. The third section is asking questions about whether the IT department viewed as a cost center. The fourth section asked about whether the organization is working on minimizing the gap between the IT strategy and business strategy. The fifth section asked respondents to use five points Likert scale to include their perceptions of the highest rated barriers to alignment and answers to this question chosen from 1-most important to 5least important.

We sent questionnaires to 100 companies; two copies (separately) were sent to each company, one addressed to the Business executive manager and the other to the IT manager. The questionnaire accompanied by a letter outlining the research project and requesting a reply within four weeks. The survey was distributed to companies within different sectors in Kuwait, depending on the number of companies accepted to do the questionnaires, 25 in the financial investment field; 15 manufactures; 25 retail companies, 20 government sector, 12 consumer goods companies, and three companies are in different fields than mentioned above. We received 57 responses. The response rate is $57 \%$ of the survey distributed.

\subsection{Result and Discussion}

The result of the survey is presented according to the main sections of the survey questionnaire.

\subsubsection{Section one - organization background information}

The first section of the survey asked for background information including job title and industry sector. Of the 57 respondent completed the questionnaires, $35(61.4 \%)$ came from executive IT managers and $22(38.6 \%)$ came from executive business managers. This differential rate of response might mean that executive business managers are less interested in answering questions about strategic 
alignment than the IT managers, or maybe they are busier people.

Respondents were from a variety of industry sectors $30 \%$ from financial, $10 \%$ from Manufacture, $10 \%$ from Retailing, $15 \%$ from Education, $19 \%$ from government and public sector, and the remainder $16 \%$ from other sectors.

\subsubsection{Section Two - IT Business Alignment}

The second section of the questionnaire concerned with more focused perceptions of alignment between business and IT strategy. When we asked the participated companies if their IT strategy aligned with their Business objectives, only $28 \%$ responded yes it is aligned. More than half $32 \%$ are not sure, and $40 \%$ said there is no alignment in their company. When we asked participant if their business managers have a good understanding of the IT objectives. $20 \%$ said yes they have; $18 \%$ are not sure, and $62 \%$ said no. When we asked participant if their IT managers have a good understanding of the Business objectives. $40 \%$ participant said yes; $35 \%$ are not sure, and $25 \%$ said no.

When we asked participant if their IT manager takes part in the formulation of the corporate strategy. $14 \%$ of the participant said yes, $23 \%$ are not sure, and $63 \%$ said that IT manager did not participate.

When we asked Participant if their IT and business managers communicate and negotiate with each other on business project. 55\% said yes there is a communication. $21 \%$ are not sure if there are any communications, and $24 \%$ said no there is no communication.

When we asked participant whether the executive business managers' perception of technology value to their company is accurate. 54\% said yes their perception was accurate; $19 \%$ they are not sure and $27 \%$ said that the business perception of technology values is not accurate.

\subsubsection{Section three - the IT department as a cost center}

Section three deals with considering the IT department as a cost center. What we mean is that IT department has no effect on the company strategy, and it is used only for technical support. $20 \%$ from the respondents either agree or strongly agree that their IT department has no strategic role in the organization's business plan, where most of the participants $45 \%$ disagree or strongly disagree with this openion. $20 \%$ of the respondent have a neutral opinion. We asked the second question about if the IT department has no effect in the company. A significant majority of respondent, $50 \%$ either disagree or strongly disagree that the IT department has no effect on the company. And only 30\% agree that IT department has no effect on the company, and only $7 \%$ of the respondents have a neutral opinion. When we asked respondent if there IT department used as a technical support function, $52 \%$ agree or strongly agree that is true, and almost $25 \%$ disagree or strongly disagree that their IT department is used as a technical support department, and only $21 \%$ has no opinion on this issue.

When we asked respondent if the expenditure on technology has any value on the business side, only $10 \%$ disagree or strongly disagree that the IT has a value on the business, where the majority of the participants almost $80 \%$ agree or strongly agree. $8 \%$ has no opinion and prefer to be neutral. When we asked the participant if the investment on IT negatively affect business productivity or customer experience, only $5 \%$ agree or strongly agree and the majority of participant $85 \%$ have disagree or strongly disagree that the IT Investment has a negative effect on business, and only $8 \%$ has a neutral decision. When we asked participants whether they thought that business executive management usually don't approve most of IT project, $15 \%$ agree or strongly agree that business executive management don't approve most of the IT projects. The majority of participants $55 \%$ disagree or strongly disagree that the executive management don't approve the IT projects, and $30 \%$ have a neutral opinion.

\subsubsection{Section four-minimizing the gap}

Section Four deals with how to minimize the gap between IT strategy and Business Strategy. When we asked participant if thee should be an IT representative in the upper management meeting. $77 \%$ agree and strongly agree that in order to minimize the gap between an IT strategy, and business strategy there should be an IT representative in the upper management meeting and only $23 \%$ totally disagree.

When we asked participant whether the decision of investment on IT technology should be taken from the organization board level rather than the IT department level, $33 \%$ agree and strongly agree that the investment on IT should be taken at executive board level rather than at the IT department level. $27 \%$ of the participant were neutral and were not sure, and $40 \%$ don't think that the IT investment decision should be taken at the board level.

When we asked participant whether business strategy and IT strategy are equally important, $80 \%$ participant agreed or strongly agreed that they are equally important. $12 \%$ said they were not sure, and $7 \%$ only said that they are not equally important.

When we asked participant if business managers should give high priority to IT projects, $67.5 \%$ agree and strongly agree that IT projects should be given a high priority from business managers. $12 \%$ were not sure, and only $7 \%$ disagree or against this idea.

When we asked participant about the involvement of business managers in the formulation of IT strategy at department level, 52\% agree and strongly agree that business managers involvement in the formulation of the IT strategy at department level is important. 33\% were not sure, and only $15 \%$ don't agree on the involvement of business managers.

When we asked participant about the involvement of IT managers in the formulation of business strategy at department level; $57 \%$ agree and strongly agree that IT managers should be involved in the formulation the business strategy. $21 \%$ were unsure, and $12 \%$ of the participant say that their IT manager has no involved in the formulation of business strategy.

\subsubsection{Section five - barriers to alignment}

We choose the answers to section-5 from a 5-point Likert scale (from 5-most important to 1-least important). Most of the participants $71 \%$ said that the ineffective communication between business management and IT management is the most important barrier to alignment.

$60 \%$ from the participants choose poor understanding among the business leaders of how IT should support business objectives is the second important barrier to alignment, and $49 \%$ said that lack of defined business strategy is the third barrier to alignment.

$40 \%$ said that weak support from IT to help the business to achieve its objectives is the fourth important barrier to 
alignment, and the least important barrier to alignment is the lack of investment in IT was $26 \%$ participants voted for it.

\section{ANALYSIS OF THE SURVEY}

Despite the importance of the alignment process, there have been relatively few studies focusing specifically on it in Kuwait. Our survey is the first research which will investigate the alignment existence on the ground, through fieldwork. The purpose of the survey is to find out whether IT/Business alignment exist and if it does not exist then what are the constrain or barriers. In addition, the survey should give an indication of business executive managers and IT manager attitudes towards and beliefs about strategic alignment.

The survey shows that $72 \%$ of the participated companies in Kuwait have said either they don't know or they have no alignment. $28 \%$ of the participated companies have said yes that their IT strategy is aligned with their Business objectives which are a very low number, and it should be taken into consideration. The Survey also shows that there is a positive attitude among business and IT managers regarding the importance and existence of alignment. The positive attitude provides some empirical evidence of the importance of the alignment process. This evidence reinforced by the fact that the alignment process is measured using two respondents (IT and business managers) in the same company. This result gives us more insight to carry on more investigation to the alignment in the real world. Both managers confirm the importance of equality preparing business and IT strategy at the same time. Meanwhile, business managers don't understand IT as $62 \%$ of participant managers said that business managers don't understand IT objectives. The former result is considered quite risky; this misunderstanding is leading to reverse actions from business managers. Doing so, business managers are considering IT department as a technical support and not as a strategic department, preventing from exploiting any opportunity may be created by IT; avoid any contact with the IT department, and preventing the organization from utilizing IT to be competitive in their sector.

As mentioned above, 54\% of the Business executive managers have reported that their perception of the IT value to the company is accurate, and $35 \%$ of the same respondent reported that IT department has an effect on the company strategic role. That means that IT has an important value to them and plays a "strategic" role in the enterprise. Additionally more than $50 \%$ say that business executive management plays a visible role in formulating the IT strategy development. Given the nature of these responses, both managers' answers to the barriers to alignment question are as follows; $70 \%$ of the executive's managers say, "ineffective communication between business/IT management" represents the most important challenge. $60 \%$ say the "Poor understanding among the business leaders of how IT should support business objectives" is the second important challenge. Nearly half (48.5\%) say "lack of defined business strategy is the third important challenge. And (40\%) say that "weak support from senior business management" is the fourth challenge, and the least important barrier to alignment is the lack of investment in IT projects "where only 26\% participant voted for it.

As mentioned above $40 \%$ of respondent said that IT managers understand business needs, such understanding enables developing joint applications that satisfy user needs, supports business strategy or shape new business strategy. On the other hand, the business managers are still facing difficulty in understanding IT objectives, the survey shows that only $20 \%$ said that they could understand IT objectives. In this situation, either the business managers don't know the latest development in the technology which led to lag in their IT knowledge or IT managers have been using some IT jargon which is not easily understood by business managers. This situation lead us to that, not only creating frequent communication channels between IT and business managers to facilitate the understanding [37, 47] but also, the IT managers should use business language. For instance, return on investment or overhead cost to measure the IT projects performance. Both managers IT and Business should acknowledge the importance of preparing their strategies together and at the same time but unfortunately they don't. This result is consistent with the concept of [20]. In terms of four types of integration, the former result gives us empirical evidence that there is a lack of communication in the administrative level as well as in full integration.

\subsection{Business executive perspective}

The survey shows that most of the business executives find it hard to understand the IT requirements and needs. Thus, it is difficult for them to participate in formulating the IT strategy, and it is also harder for them to communicate with IT executives. The survey also shows that $63 \%$ of participants said that IT managers do not participate in the formulation of the corporate strategy. This result also indicates that business executives don't think that it is important to the company to call the IT managers to participate in the formulation of the company strategy. This result also justifies the barrier why there is poor understanding between business leaders on how IT should support business objective.

Another important point to be highlighted is that only $20 \%$ from the respondents strongly agree that their IT department has no strategic role in the company, and this is obviously coming from the business executives' side who don't see the value of the IT resources in their company.

The survey also shows that there is a split decision between the IT executive managers and the Business executive managers on whether the IT department has an effective role on the company. $50 \%$ from participants said that the IT has an effect on the company performance and the other $50 \%$ say there is no effect that comes from the business managers side.

The business executive managers also claim that the IT department is used as a technical support function only, and this is to justify their claim that the IT department has no strategic role in the company.

\subsection{IT executive perspective}

Despite the fact that both IT and business managers think that IT and business strategies are equally important, therefore, should be aligned. They disagree on the alignment process. IT managers strongly support that they should participate in the formulation of the corporate strategy, and there should be an IT representative in the upper management meeting as well. On the other hand, they disagree with the concept of taking the decision of investment on IT technology from the organization board level rather than IT department level.

Most of the business executive participants say that the IT department has no effect on the company. $80 \%$ of the participants (which is more than the number of IT executives participated) agree that the IT expenditure has a business value, which shows that most of the IT applications are perfectly used by the business units. This point of view is supported by $85 \%$ of the participants which they disagree with 
the statement that say IT investment has a negative effect on the business objectives.

Therefore, we can find out from the survey that lack of communication and poor understanding are the most rated barriers between the IT and business managers in order to apply the process of alignment between them. The executive managers should communicate more often in order to understand each other and work on the alignment process accordingly.

\section{CONCLUSION}

This paper describes our investigation in the organizations operating in the Kuwaiti market considering the existence of the IT/Business alignment based on the attitudes of the business executive and IT managers towards alignment within these selective companies. During the fieldwork, we have found that most of the selected companies in Kuwait use the IT department as a technical support department, and it is not treated as a strategic partner to the business departments. We think that the reason is the lack of communication, and lack of integration between IT/business departments and these barriers remains as unsolved issued.

In addition, most of the companies participated claimed that there is no proactive dialogue between IT and business departments at the administration level. When they do communicate, it is always difficult for the business managers to understand the IT Jaron. This issue made the business executives to have no interest in listening to the IT problems and therefore they do not call them to participate in formulating a business strategy.

Therefore, we recommend, as IT becoming very important to the development and delivery of business strategy, more attention needs to be paid to the alignment of business/IT strategy development than it has been paid for in the past. Hence, executive managers from both groups must continue to work together to understand their challenges and opportunities, as well as their goals.

\section{REFERENCES}

[1] Aldridge, A. and A.L. Harris, (1999), "Implementing ITbased Systems: Lessons from the Retail Industry", Journal of Computer Information Systems, 39:2, Pp. 54.

[2] Avison, D., Jones, J., Powell, P. \& Wilson, D. (2004), "Using and Validating the strategic alignment model", Journal of Strategic Information Systems, 13, Pp. 223246.

[3] Behling, R. and H. Records. (1995), "Technology and International Competition in the Information Age", Journal of Computer Information Systems, 35:2, Pp. 50.

[4] Brancheau, J., Janz, B., \& Wetherbe, J. (1996), "Key issue in information systems management: 1994-1995 SIM Delphi result”. MIS Quarterly 20, Pp225-242.

[5] Broadbent, M. and P. Weill, (1993), "improving Business and Information Strategy Alignment: Learning from the Banking Industry", IBM Systems Journal, 32(1), Pp. 162-179.

[6] Bruce, K. (1998), Can you align IT with business strategy? Strategy \& Leadership, Nov- Dec. 1998, 26(5). Pp. 16.

[7] Byrd, T. \& Turner, D. E. (2000). Measuring the Flexibility of Information Technology Infrastructure:
Exploratory Analysis of a Construct. Journal of Management Information Systems, 17 (1), 167-208.

[8] Carr. N. G. (2003) "IT Doesn't Matter." Harvard Business Review, Vol. 81, No. 5, Pp. 41-49.

[9] Chan, Y. E. and B. H. Reich (2007). IT alignment: what have we learned? Journal of Information Technology (2007) 22, pp. 297-315.

[10] Chan, Y. E., Sabherwal, R. \& Thatcher, J. B. (2006), "Antecedents and outcomes of strategic IS Alignment An Empirical Investigation", IEEE Transaction on Engineering Management, 53(1), 27-47.

[11] Choe, J. (2003)' "The effect of environment uncertainty and strategic applications of IS on a firm's performance", Information \& Management, Vol. 40 No 4, pp257-268.

[12] Croteau, A. M. \& Ramond, L. (2004), "Performance outcomes of strategic and IT competencies alignment", Journal of information Technology, 19, Pp. 178-190.

[13] Feeny, David F. \& Leslie P. Willcocks. (1998), "Redesigning the IS function around core capabilities", Long Range Planning, 31(3): 354-67.

[14] Galliers, R. (1991), "Strategic information systems planning; myths, reality and guidelines for successfu implementation", European Journal of Information Systems, Vol.1, Iss.2, pp.55-64

[15] Gomolski, B. (2002) "IT Power Shift: Putting the Business in the Driver's Seat", Gartner Symposium ITXPO 2002, 26A, October 2002, SYM12, Pp. 1-16.

[16] Gottschalk, P. (2000) "Studies of key issues in IS management around the world", International Journal of Information Management 20, Pp 169-180.

[17] Henderson, J. C., \& Venkatraman, N. (1993), "Strategic Alignment: Leveraging information technology for transforming organizations", IBM Systems Journal, Vol.32, Iss1, pp.472.

[18] Huang, C. D., \& Hu, Q. (2007), “Achieving IT-Business Strategic Alignment via Enterprise-Wide Implementation of Balanced Scorecards", Information Systems Management, Vol.24, pp.173-184.

[19] Keen, P. (1991), "Every Manager's Guide to Information Technology", Harvard Business School Press, Boston, MA

[20] King, W. R., \& Teo, T. (1996) "Integrating between business planning and information systems planning", Information and Management 1Vol 30, Pp309-321.

[21] King, W.R. and Y.A. Pollalis. (2001), "IT-based Coordination and Organizational Performance: A Gestalt Approach", Journal of Computer Information Systems, $41: 2$, p. 64

[22] Lederer, A. L., \& Mendelow, A. L. (1989), "Coordination of information systems plans with business plans," Journal of Management Information Systems, Vol.6, Iss.2, pp.5-19.

[23] Liebowitz, J. (1999),"Information Systems: Success or Failure?",Journal of Computer Information Systems, 40:1, p. 17

[24] Levy, D. L. (2000), “Applications and Limitations of Complexity Theory in Organization Theory and 
Strategy”, In J. Rabin, G. J. Miller \& W. B. Hildreth (Eds.), Handbook of Strategic Management (2nd ed) (pp. 67-87), "New York: Marcel.

[25] Luftman, J., Papp, R., \& Brier, T. (1999), “Achieving and Sustaining Business-IT alignment", California Management Review, Vol.42, Pp. 109.

[26] Luftman, J. (2000), “Assessing Business-IT Alignment Maturity", Communications of the Association for information Systems, Vol.4 (Article 14).

[27] Luftman, J.N. (2005), "Key Issues for IT executives 2004”, MIS Quarterly Executives, Vol. 4, No. 2, pp 1-5.

[28] Luftman, J.N., Kempaiah, R., and Nash, E. (2006), "Key issues for IT executives 2005", MIS Quarterly Executive, Vol. 5, 2, 27-45.

[29] Oz, E. and JJ. Sosik. (2000), "Why Information Systems Projects are Abandoned: A Leadership and Communication Theory and Exploratory Study", Journal of Computer Information Systems, 41:1,pp.66.

[30] Palmer, J. W>, \& Markus, M. L. (2000), "The performance impacts of quick response and strategic alignment in specialty retailing" Information Systems Research, Vol. 11, Iss. 3, pp.241.

[31] Pollalis, Y .A. (2003), " Pattern of co-alignment in an information-intensive organization: business performance through integration strategies", International Journal of Information Management, Vol. 23, No. 6, pp 469-492.

[32] Portet, M. E. (1985), Competitive Advantage: Creating and Sustaining Superior Performance, 'New York: Free Press.

[33] Papp, R. (1995), "Determinants of strategically Aligned Organizations: a Multi-Industry, Multi-perspective Analysis", Hoboken, NJ, Steven Institute of Technology.

[34] Papp, R. (2001), "Strategic Information Technology: Opportunities for Competitive Advantage", IDEA Publishing Group.

[35] Rangan, S. \& Adner, R. (2001) "Profits and the internet: seven misconceptions", Sloan Management Review, Vol. 42 No. Pp 444-453.

[36] Reich, B. \& Benbasat, I. (1996). "Measuring the Linkage between Business and Information Technology Objectives”, MIS Quarterly, Vol. 20, No. 1, Pp. 55-81.

[37] Reich, B. \& Benbasat, I. (2000), "factors that influence the social dimension of alignment between business and information technology objectives", MIS Quarterly 24, Pp81-113.

[38] Rockrat, J.F. (1988) "The line takes the leadership - IS Management in a Wired Society", Sloan Management Review, Vol. 29. Pp 57-64.

[39] Rockart, J. F. et al., (1996), "The New IT Organisation: Eight Imperatives", Massachusetts Institute of Technology, Sloan WP 3902.

[40] Sabherwal, R. and Chan, Y. E. (2001), "Alignment between Business and IS Strategies: A study of Prospectors, Analyzers, and Defenders", Information System Research, 12(1), Pp. 11-33.

[41] Sabherwal, R., Hirschheim, R., \& Goles, T. (2001), "The Dynamics of Alignment: Insights from a Punctuated Equilibrium Model the Dynamics of Alignment: Insights from a Punctuated Equilibrium Model", Organisation Science, Vol.12, Iss.2, pp.179-197.

[42] Shin, N. (2002) Creating Business Value with Information Technology: Challenges and Solutions Hershey, P. A. Idea Group Inc.

[43] Shore, B. (1996) "Using Information Technology to Achieve Competitive Advantage: A Study of Current and Future Trends", Journal of Computer Information Systems, 36:4, p. 54.

[44] Sid Diamond, (1994), "giving business an IT alignment aligning information technology functions with business operations", Software Magazine, February, 1994.

[45] Smaczny, T. (2001), "Is an Alignment between Business and IT the Appropriate Paradigm to Manage IT in Today's Organisation?”, Management Decision, 39(10).

[46] Tallon, P.P., K. L. Kraemer and V. Gurbaxani, (2000) 'Executives' Perceptions of the business value of Information Technology: A Process-Oriented Approach", Journal of Management Information Systems. 16(4), pp. 145-156.

[47] Teo, T. \& Ang, j. (1999), "Critical Success Factors in the alignment of IS Plans with Business plans", Informational Journal of Information Management 19 , Pp173 - 185 .

[48] Teo, T. \& King, W. (1996) "Assessing the Impact of Integrating Business Planning and IS planning", Information \& Management 30, Pp309-321.

[49] WILLCOCKS, L. (1994). Information Management: the evaluation of information Systems investments, London, Chapman \& Hall. 